\title{
Manganese-Nanoparticles Substitutions on the Vanadium Sites of Bi-Sr-Vanadate Aurivillius Ceramics
}

\author{
Khaled M. Elsabawy, ${ }^{1,2}$ M. M. Abou-Sekkina, ${ }^{1}$ A. El-Maghraby, ${ }^{2,3}$ and M. A. Asker ${ }^{1}$ \\ ${ }^{1}$ Materials Science Unit, Chemistry Department, Faculty of Science, Tanta University, Tanta, Egypt \\ ${ }^{2}$ Materials Science Unit, Chemistry Department, Faculty of Science, Taif University, 888-Alhawyah-Taif, Saudi Arabia \\ ${ }^{3}$ Ceramic Unit, Chemistry Department, National Research Center, Tahrir Street, Dokki, Egypt \\ Correspondence should be addressed to Khaled M. Elsabawy, ksabawy@yahoo.com
}

Received 3 November 2011; Revised 18 January 2012; Accepted 24 January 2012

Academic Editor: Hakan Arslan

Copyright (๑) 2012 Khaled M. Elsabawy et al. This is an open access article distributed under the Creative Commons Attribution License, which permits unrestricted use, distribution, and reproduction in any medium, provided the original work is properly cited.

\begin{abstract}
The aurivillius phase of Mn-substituted samples with general formula $\mathrm{Bi}_{2} \mathrm{SrV}_{2-x} \mathrm{Mn}_{x} \mathrm{O}_{9}$, where $x=0.05,0.1,0.2,0.3$, and 0.6 mole were prepared by solid-state reaction technique and ceramics procedures. The X-ray structural measurement analysis confirmed the formation of single-phase-layered hexagonal structure which is observed in all samples. The thermal stability and phase change of the green powders were studied by thermogravimetric analysis (TGA) and differential thermal analysis (DTA). SEM revealed that the average grain size increases with increasing $\mathrm{Mn}$ content. The infrared absorption spectra recorded a series of vibrational modes within the range of $400-1600 \mathrm{~cm}^{-1}$ were investigated. The present work also studied the effect of Mn-doping concentration interactions on both DC-electrical conductivity and ESR spectra.
\end{abstract}

\section{Introduction}

Ferroelectic aurivillius ceramic has attracted the attention of many investigators due to its potential applications in electronics devices (DRAMs) [1-3]. Recently, there is interest in the study of bismuth-layered-structured ferroelectric materials for memory applications; one of the bismuthlayered-structured compounds is a promising candidate for ferroelectric random access memories (FRAM) as it has very little fatigue under polarization switching [4]. The study of microstructure of the SBN thin film is very important $[5,6]$. The antiphase boundaries [APBs] are important factors of Bi-layered perovskite properties [7-9]. The layered crystal structure compounds have an anisotropic lamellar morphology, in which the major faces of the lamellar are perpendicular to the $\mathrm{c}$-axis of the structure.

In order to use moderate sintering temperatures so as to prevent compositional changes and exaggerated grain growth, and to attain low porosity, the ceramics of these compositions must be prepared by hot pressing technique [10-13].

Several bismuth-layered perovskites such as strontium bismuth niobate [SBN] [12] and strontium bismuth tantalate
[SBT] [14] have been shown to exhibit much elongated fatigue durability and are capable of withstanding $10^{12}$ erase and rewrite operations. It is found that the substitution of niobium with vanadium in $\mathrm{SrBi}_{2} \mathrm{Nb}_{2} \mathrm{O}_{9}$ leads to enhancement of ferroelectric properties together with a lowered processing temperature $[15,16]$.

It has recently been reported that there occurs $\left(\mathrm{BiFeO}_{3}\right)$ doped $\mathrm{Sr} \mathrm{Bi} \mathrm{Nb} \mathrm{[17].} \mathrm{Most} \mathrm{of} \mathrm{the} \mathrm{work} \mathrm{of} \mathrm{the} \mathrm{layered}$ perovskite $\mathrm{Sr} \mathrm{Bi}$ oxides reported on the improvement of the dielectric and ferroelectric properties is based on A-site substitution $[18,19]$. For example, the replacement of $\mathrm{Sr}^{2+}$ ions by a smaller cations $\mathrm{Ca}^{2+}$ results in an increase in its dielectric content and Curies temperature $T_{c}$ [20].

Coondoo et al. reported the effect of tungsten substitution for tantalum on the structural, dielectric and impedance properties, of $\mathrm{SrBi}_{2} \mathrm{Ta}_{2} \mathrm{O}_{9}$ ferroelectric ceramics [21]. It was difficult to accommodate the $\mathrm{Mn}^{3+}$ ion with large ionic radius to the lattice because the ionic radius of the $\mathrm{La}^{3+}$ ion was smaller than that of the $\mathrm{Sr}^{2+}$ ions $[22,23]$.

It is well known that the addition of $3 \mathrm{~d}$ transition metals for example, $\mathrm{Mn}, \mathrm{Fe}, \mathrm{Cr}$, and $\mathrm{Cu}$ improves the dielectric properties of bismuth strontium titanate and that $\mathrm{Mn}$ is 
the most effective among them; Mn ions are believed to substitute Ti and act as acceptors [24-26]. Recently, it was found by Liu and Fan that $\mathrm{Ca}$ and Mn codoping affects the structure and dielectric properties of sol-gel derived BST ceramics [27].

Recently many researchers [28-31] have investigated conductivity, dielectric, structure, substitutions effects, and magnetic properties of different molecular formulas of aurivilius phases such as $\mathrm{Bi}_{2.5} \mathrm{Gd}_{1.5} \mathrm{Ti}_{3} \mathrm{O}_{12}, \mathrm{PbBi}_{4} \mathrm{Ti}_{4} \mathrm{O}_{15}$, $\mathrm{BaBi}_{3.8} \mathrm{M}_{0.2}\left(\mathrm{Ti}_{3.8} \mathrm{Nb}_{0.2}\right) \mathrm{O}_{15}$ where $(\mathrm{M}=\mathrm{Ba}, \mathrm{Sr}, \mathrm{Mg}$ and $\mathrm{Ba}$, $\mathrm{Mn}$ ) and most of them confirmed that substitutions on the different sites of aurivillius phases affect sharply and remarkably on both of structural and physical properties.

The essential goal of the present paper is to investigate wide range of $\mathrm{Mn}$-dopings on vanadium sites of $212 \mathrm{Bi}-\mathrm{Sr}$ $\mathrm{V}-\mathrm{O}$ regime on;
(a) Structural and microstructural properties,
(b) Thermal and processing temperature,
(c) Spectroscopic properties (IR, ESR),
(d) Conduction behaviour of 212-Bi-Sr-V-O system.

\section{Experimental}

The pure $\mathrm{Bi}_{2} \mathrm{SrV}_{2} \mathrm{O}_{9}$ and doped samples with the general formula $\mathrm{Bi}_{2} \mathrm{SrV}_{2-x} \mathrm{Mn}_{x} \mathrm{O}_{9}$, where $x=0.05,0.1,0.2,0.3,0.6$ mole and were prepared by conventional solid state reaction route and sintering procedure using (physical method) the appropriate amounts of $\mathrm{Bi}_{2}\left(\mathrm{CO}_{3}\right)_{3}, \mathrm{SrCO}_{3},\left(\mathrm{NH}_{4}\right)_{2} \mathrm{VO}_{3}$ and $\mathrm{MnO}$ (each purity $>99 \%$ ). The particles size of $\mathrm{MnO}$ used as dopant ranged between $60-90 \mathrm{~nm}$. The mixture was ground in an agate mortar for one hour. Then the finely ground powder was subjected to firing at $800^{\circ} \mathrm{C}$ for 10 hours, reground and finally pressed into pellets $\left(8 \mathrm{Ton} / \mathrm{cm}^{2}\right)$ with thickness $0.2 \mathrm{~cm}$, diameter $1.2 \mathrm{~cm}$, and Sintered at $850^{\circ} \mathrm{C}$ for 10 hours. Then the furnace is cooled slowly down by rate $-5^{\circ} / \mathrm{min}$, to room temperature. Finally, the materials are kept in vacuum desiccator over silica gel dryer.

\subsection{Structural Measurements}

2.1.1. X-Ray Diffraction (XRD). The X-ray diffraction measurements (XRD) were carried out at room temperature on the fine ground $\mathrm{Bi}_{2} \mathrm{SrV}_{2} \mathrm{O}_{9}$ and $\mathrm{Bi}_{2} \mathrm{SrV}_{2-x} \mathrm{Mn}_{x} \mathrm{O}_{9}$ systems in the range $\left(2 \theta=10-70^{\circ}\right)$ using $\mathrm{Cu}-\mathrm{K} \alpha$ radiation source and a computerized [Bruker Axs-D8 advance] X-ray diffractometer with two-theta scan technique.

2.1.2. Scanning Electron Microscopy. Scanning electron microscope (SEM) measurements were carried out using small pieces of prepared samples on different sectors to be the actual molar ratios by using "TXA-840, JEOL-Japan" attached to XL30 apparatus with EDX unit, accelerant voltage $30 \mathrm{kv}$, magnification $10 \mathrm{x}$ up to $500.000 \mathrm{x}$ and resolution $3 \mathrm{~nm}$. The samples were coated with gold.

2.2. Conductivity Measurements. The DC-electrical conductivity of the samples was measured using the two terminals
DC method. The pellets were inserted between spring loaded copper electrodes, and A KEITHLEY 175 multimeter (ASA) was employed from room temperature up to $500 \mathrm{~K}$. The temperature was measured by a calibrated chromel-alumel thermocouple placed firmly at the sample. Energy gab $\left(E_{g}\right)$ and the number of $\left(\mathrm{e}^{-}\right)$in conduction band $N_{\mathrm{cb}}$ increase as the ratio of $\mathrm{Mn}$ doping increases from $x=0.05$ to $x=0.6$ mole. The calculations of $E_{g}$ and $N_{\mathrm{cb}}$ were estimated according to (1) and (2) as shown below,

$$
\begin{gathered}
\rho=\rho_{o} e^{-\Delta E_{g} / K T}, \\
N_{\mathrm{cb}}=A T^{3 / 2} e^{-E_{g} / 2 K T},
\end{gathered}
$$

where in (1) $\rho$ and $\rho_{o}$ are conductance and specific conductance, respectively. $K$ is Boltezmann constant and $T$ is absolute temperature in Kelvin. Measurements were conducted in such a way that at each temperature, sufficient time was allowed to attain thermal equilibration.

2.3. Thermal Analyses Measurements. The thermogravimetric analysis (TGA) and the differential thermal analysis (DTA) measurements were carried out on the green mixtures (starting powders) of the prepared samples using a computerized Shimadzu c Japan TGA/DTA analyzer and $\mathrm{Al}_{2} \mathrm{O}_{3}$ as a reference for DTA measurements.

2.4. Solid Infrared Absorption Spectral Measurements. The IR absorption spectra of the prepared samples were recorded using "Nexus 670 FT IR spectrometer in the range 500$2500 \mathrm{~cm}^{-1}$ using pure $\mathrm{KBr}$ matrix."

2.5. Electron Paramagnetic Resonance Measurements. The electron spin resonance spectra (ESR) were recorded at room temperature for the prepared samples at $x$-band frequencies on a "Bruker- ELEXSYS E 500 Germany" spectrometer at the National Research Center, Egypt.

\section{Results and Discussion}

\subsection{Phase Identification}

3.1.1. X-Ray Diffraction. Figure 1(a)-(f) displays the X-ray diffraction patterns of pure and $\mathrm{Mn}$-doped samples having the general formula $\mathrm{Bi}_{2} \mathrm{SrV}_{2-x} \mathrm{Mn}_{x} \mathrm{O}_{9}$, where $x=0.05,0.1$, $0.2,0.3,0.6$ mole.

Analysis of the corresponding $2 \theta$ values and the interplanar spacings $d(\AA)$ by using computerized program proved that the compound mainly belongs to distorted aurivillius structure type with hexagonal crystal form, that expressed by assigned peaks. The unit cell dimensions were calculated using parameter of the most intense $\mathrm{X}$-ray reflection peaks and is found to be $\mathrm{a}=\mathrm{b}=5.7804 \AA$ and $\mathrm{c}=7.104 \AA$ for the pure $212 \mathrm{Bi}-\mathrm{Sr}-\mathrm{V}-\mathrm{O}$ regime.

The refinement of X-ray diffraction pattern indicated that the fraction volume of pure phase is reaching to $\sim 93 \%$ while $\sim 88 \%$ for Mn-substituted aurivillius ceramic.

The substitution of $\mathrm{Mn}$ for $\mathrm{V}^{5+}$ would induce B-site cation vacancies in the aurivillius layer structure which leads 


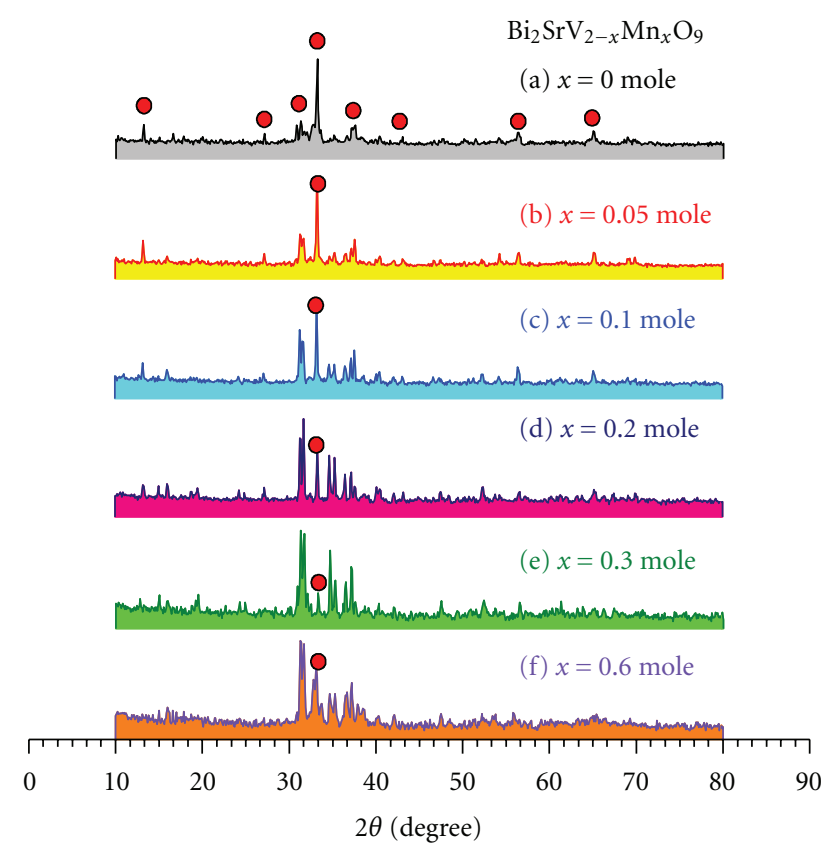

FIGURE 1: XRD patterns recorded for (a) pure $\mathrm{Bi}_{2} \mathrm{SrV}_{2} \mathrm{O}_{9}$ and Mndoped samples, (b) $\mathrm{Bi}_{2} \mathrm{SrV}_{1.95} \mathrm{Mn}_{0.05} \mathrm{O}_{9}$, (c) $\mathrm{Bi}_{2} \mathrm{SrV}_{1.9} \mathrm{Mn}_{0.1} \mathrm{O}_{9}$, (d) $\mathrm{Bi}_{2} \mathrm{SrV}_{1.8} \mathrm{Mn}_{0.2} \mathrm{O}_{9}$, (e) $\mathrm{Bi}_{2} \mathrm{SrV}_{1.7} \mathrm{Mn}_{0.3} \mathrm{O}_{9}$, (f) $\mathrm{Bi}_{2} \mathrm{SrV}_{1.4} \mathrm{Mn}_{0.6} \mathrm{O}_{9}$.

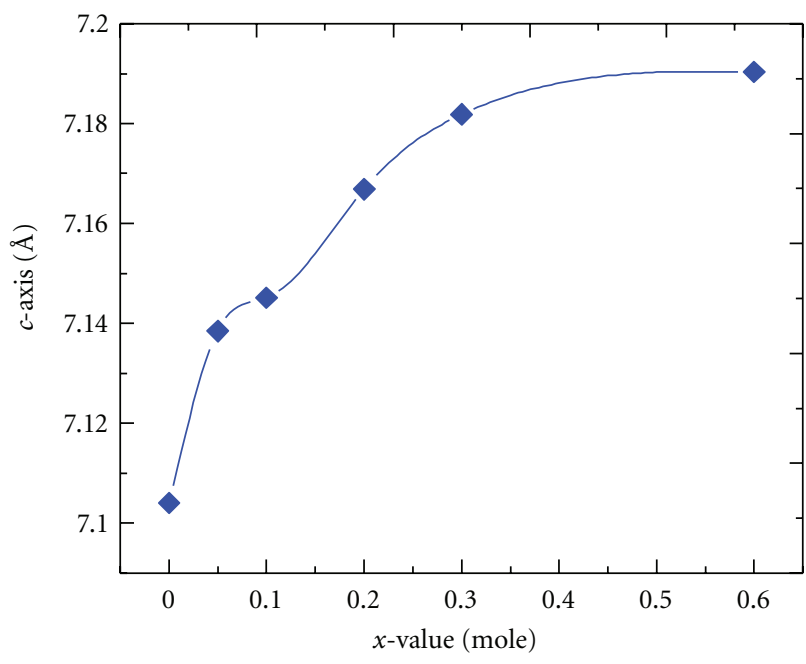

FIgURE 2: The variation of $c$-axis versus Mn-content.

to an increasing of internal stress for the shrinkage of unit cell volume. It is observed that the single phase layered auivillius structure is obtained in the range $0 \leq x \leq 0.6$ since the intensity of the peaks increases as the Mn doping increases. The lattice parameter c shows an increasing as the $x$-values increase, due to the stress inside the lattice which leads to increase the shrinkage of lattice (Figure 2).

From Figure 1(a)-(f) one can observe that the substitution of $\mathrm{Mn}$ are successful in all ranges up to 0.6 mole and there is no evidence for impurities in the diffractogram so, the Mn-dopant can substitute in the V-sites successfully in all ranges $[18,32]$. Only remarkable observation is decreasing the intensities of maximum intense assigned by black circles as Mn-doping increases that reflects the decreasing of major phase as Mn-dopings ratio increase.

3.1.2. Microstructural Properties (SEM). Figures 3(a), 3(c) and 3(e) displays the SEM-micrographs captured for the synthesized materials. The grain size of pure $212 \mathrm{BiSrV}$ is found to be $1.5 \mu \mathrm{m}$. The presence of bismuth leads to attraction between the grains with each other and porous structure appeared between the grains due to bismuth evaporation (Figure 3(a), 3(c) and 3(e)).

The grain size increased drastically with increase of $\mathrm{Mn}$ addition from 0.1 to 0.3 moles and found to be in between $2.49-2.6 \mu \mathrm{m}$, respectively. The ionic radius of $\mathrm{Mn}^{2+}$ is $67 \mathrm{pm}$ which is close to the ionic radius of $\mathrm{V}^{5+} 58 \mathrm{pm}, \mathrm{Mn}$ will replace $\mathrm{V}$ at the $\mathrm{B}$-site of the perovskite $\mathrm{ABO}_{3}$ structure and bring the distorted perovskite unit cell, which promotes the grain growth as observed in Figures 3(a), 3(c) and 3(e). The doping of $\mathrm{Mn}$ ions have the tendency to rearrange and aggregate within limited space, leading to an increase in the size of particles and distortion of crystal [28].

3.1.3. (TGA and DTA) Thermal Analyses Measurements. The thermogravimetric analysis (TGA) and differential thermal analysis (DTA) measurements were carried out on the green mixture of pure 212BiSrV and some selected Mn-doped samples with general formula $\mathrm{Bi}_{2} \mathrm{SrV}_{2-x} \mathrm{Mn}_{x} \mathrm{O}_{9}$, where $x=$ 0.1 and 0.3 mole.

Owing to the two curves TGA and DTA Figures 4(a) and 4(b) for samples a, c, and e, respectively, the TGA analysis was constituent with four stages, a gradual mass loss from room temperature to $250^{\circ} \mathrm{C}$ can be assigned to the evaporation and elimination of the bonded water and decomposition of ammonium vanadate to $\mathrm{NH}_{3}$ and vanadium oxide. The mass loss in the temperature range from $250^{\circ} \mathrm{C}$ to $450^{\circ} \mathrm{C}$ was mainly caused by the decomposition of $\mathrm{Bi}_{2}\left(\mathrm{CO}_{3}\right)_{3}$ into $\mathrm{Bi}_{2} \mathrm{O}_{3}$ and $\mathrm{CO}_{2}$. The third loss region from $450^{\circ} \mathrm{C}-700^{\circ} \mathrm{C}$ is due to partial decomposition of $\mathrm{SrCO}_{3}$ incorporated with the initial phase formation reaction. The further mass loss beyond $700^{\circ} \mathrm{C}$ was owing to the formation of solid state oxide and the release of $\mathrm{CO}_{2}$ results from the final decomposition of $\mathrm{SrCO}_{3}$. Moreover, it could be found in the (DTA) curves that there existed different endothermic and exothermic peaks which clearly exhibited the formation of solid state oxides with an increase in an annealing temperature [33].

3.2. Electron Paramagnetic Resonance Measurements. Figure 5 (a), (c) and (e) shows the ESR spectra for pure $212 \mathrm{BiSrVO}$ and different $\mathrm{Mn}$ concentration with the general formula $\mathrm{Bi}_{2} \mathrm{SrV}_{2-x} \mathrm{Mn}_{x} \mathrm{O}_{9}$, where $x=0.1$ and 0.3 mole. It is clearly seen that the effective $g$-values $\left(g_{\text {iso }}\right)$ exhibit an increase from $x=0.0$ mole to $x=0.3$ mole due to the strong coupling between $\mathrm{Mn}^{2+}$ and $\mathrm{V}^{5+}$ ions successfully at low dopant concentration (Figure 6). The anisotropy occurred as a result of dopant cation and/or lattice defects could be the reason why $g$ effect varies as a function of dopant cation $[34,35]$. Furthermore it is well known that $\mathrm{Mn}^{+m}$ under thermal treatment program is possible to be oxidized into multi oxidation states such as $\mathrm{Mn}^{+2}, \mathrm{Mn}^{+3}, \mathrm{Mn}^{+4}, \ldots, \mathrm{Mn}^{+7}$ 

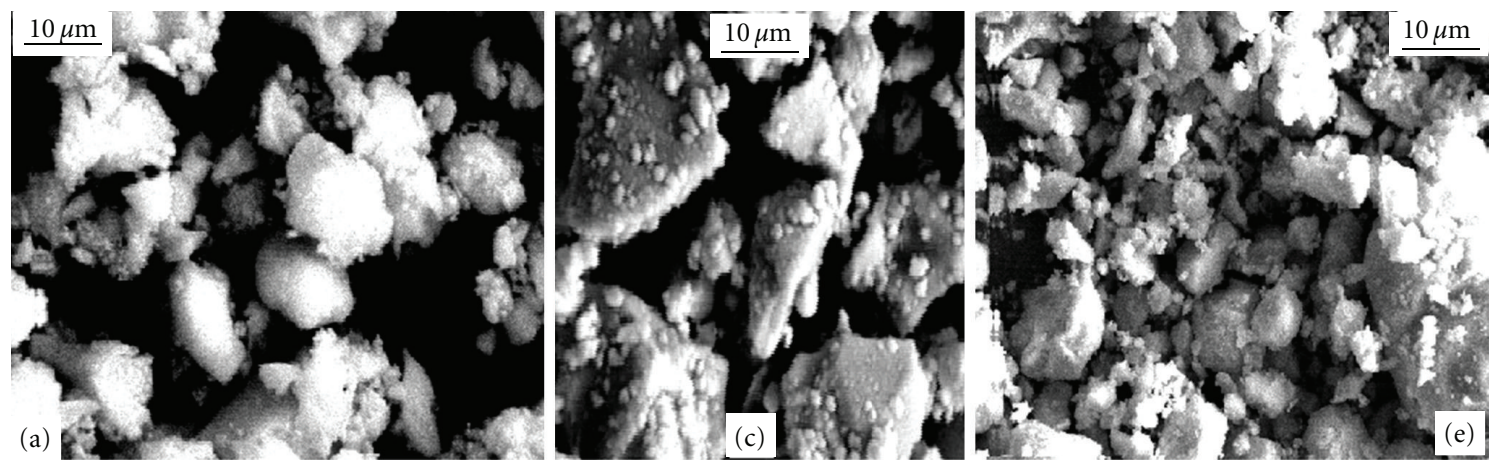

FIGURE 3: SE-micrograph images recorded for pure and some selected Mn-doped 212-Bi-Sr-V-O system with two different magnification factors 2000x $\mu \mathrm{m} \& 5000 \mathrm{x} \mu \mathrm{m}$ where (a) $\mathrm{Bi}_{2} \mathrm{SrV}_{2} \mathrm{O}_{9}$, (c) $\mathrm{Bi}_{2} \mathrm{SrV}_{1.9} \mathrm{Mn}_{0.1} \mathrm{O}_{9}$ and (e) $\mathrm{Bi}_{2} \mathrm{SrV}_{1.7} \mathrm{Mn}_{0.3} \mathrm{O}_{9}$.

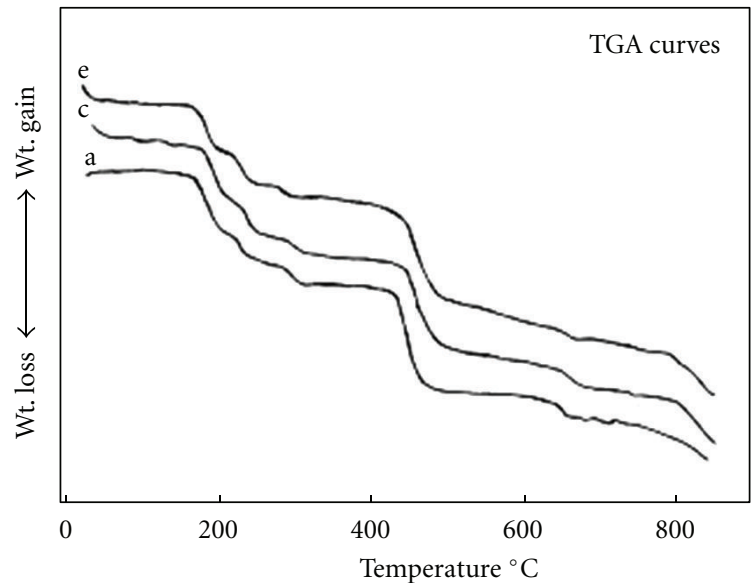

(a)

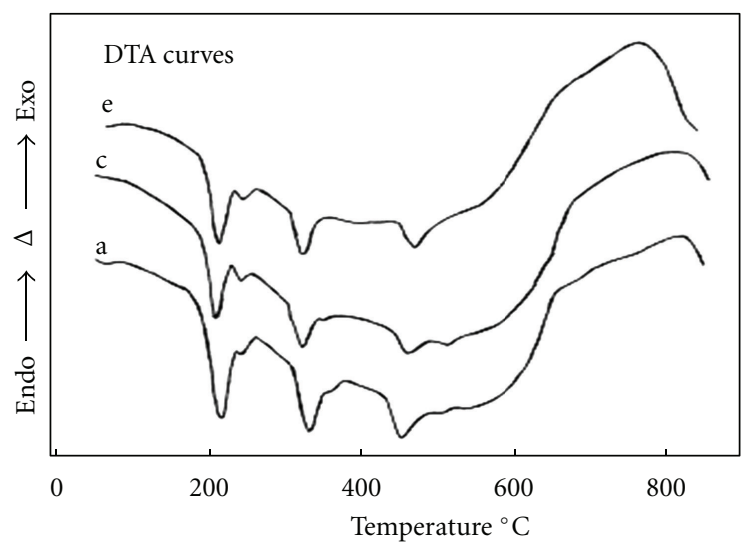

(b)

FIGURE 4: Thermogravimetric (TGA) and differential thermal analyses (DTA) curves recorded for green mixture of pure and some selected Mn-doped 212-Bi-Sr-V-O system where (a): $\mathrm{Bi}_{2} \mathrm{SrV}_{2} \mathrm{O}_{9},(\mathrm{c}): \mathrm{Bi}_{2} \mathrm{SrV}_{1.9} \mathrm{Mn}_{0.1} \mathrm{O}_{9}$ and (e): $\mathrm{Bi}_{2} \mathrm{SrV}_{1.7} \mathrm{Mn}_{0.3} \mathrm{O}_{9}$.

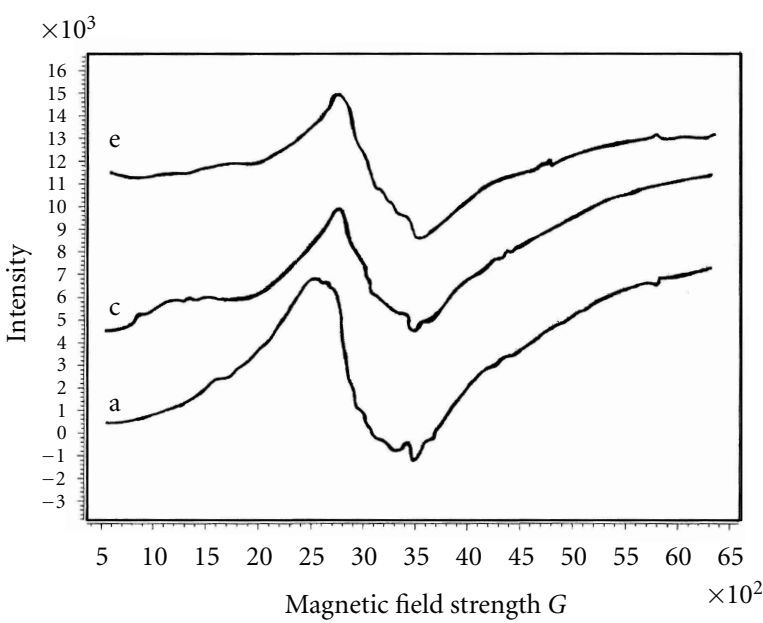

FIGURE 5: ESR spectra at room temperature for pure and some selected Mn-doped 212-Bi-Sr-V-O system where (a) $\mathrm{Bi}_{2} \mathrm{SrV}_{2} \mathrm{O}_{9}$, (c) $\mathrm{Bi}_{2} \mathrm{SrV}_{1.9} \mathrm{Mn}_{0.1} \mathrm{O}_{9}$ and (e) $\mathrm{Bi}_{2} \mathrm{SrV}_{1.7} \mathrm{Mn}_{0.3} \mathrm{O}_{9}$.

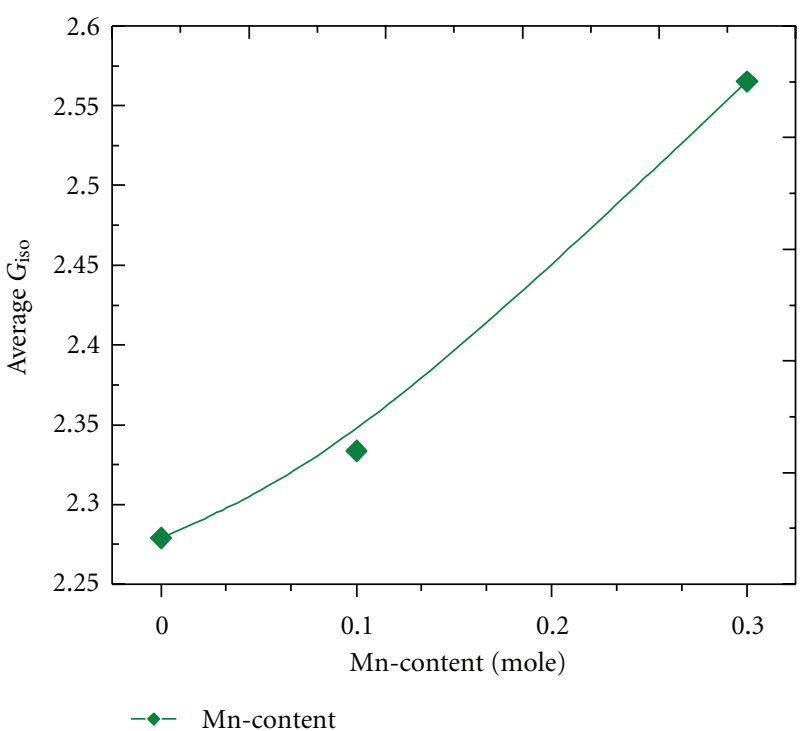

FIGURE 6: The relationship between $G_{\text {iso }}$ and $x$-values of Mncontent. 


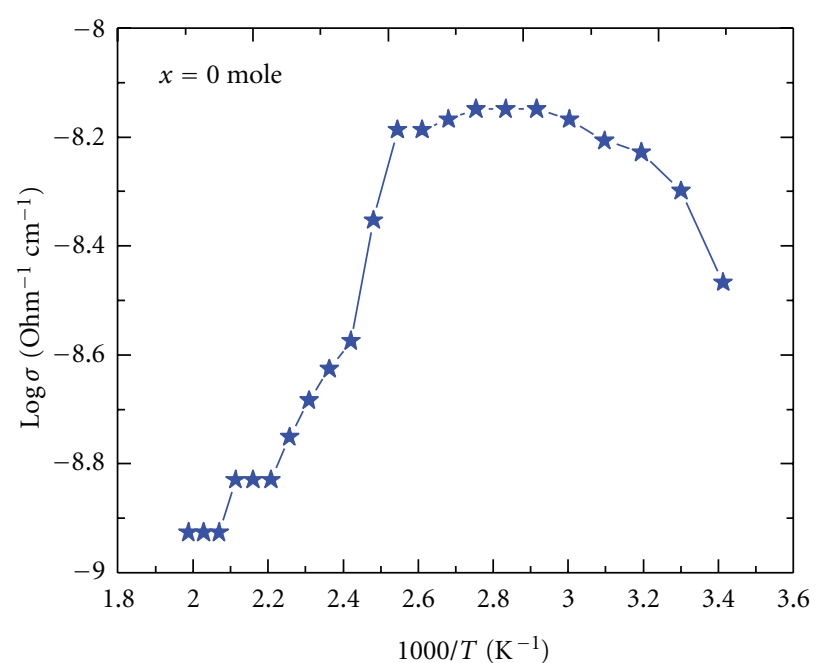

(a)

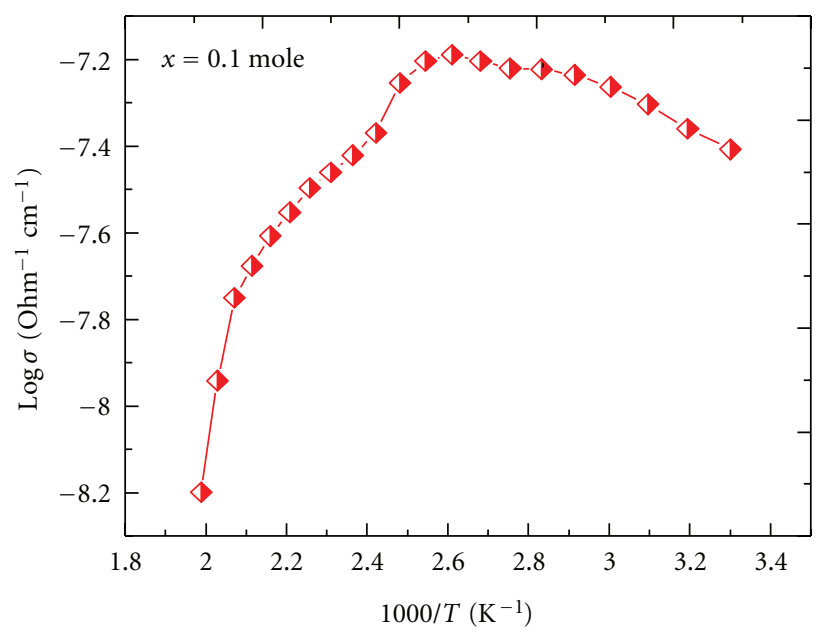

(c)

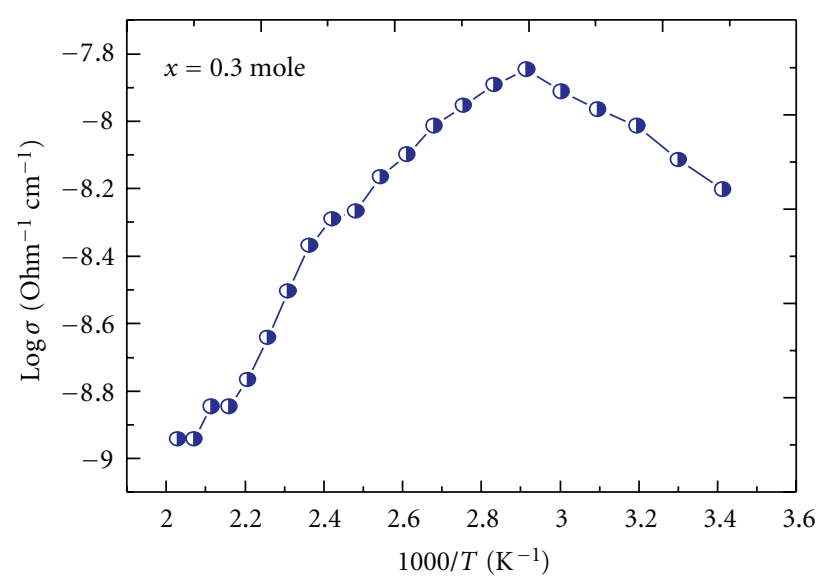

(e)

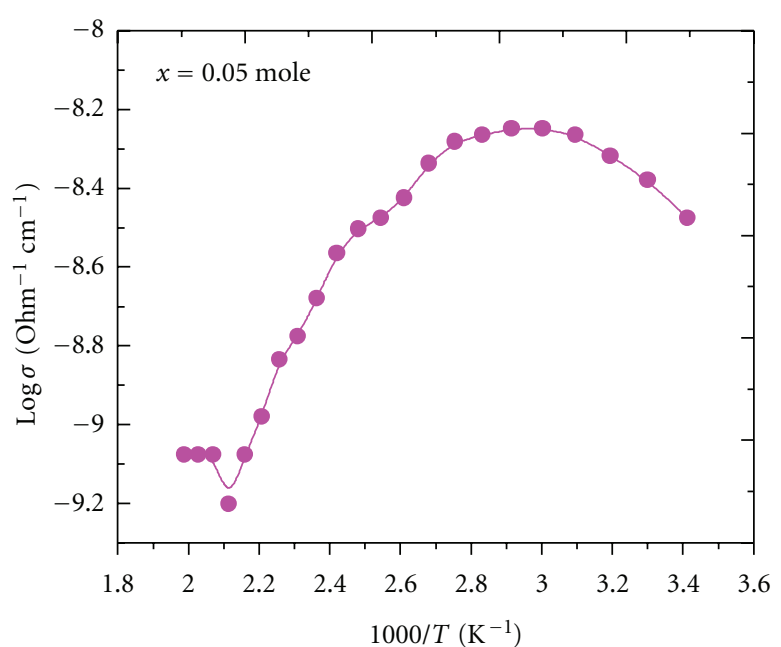

(b)

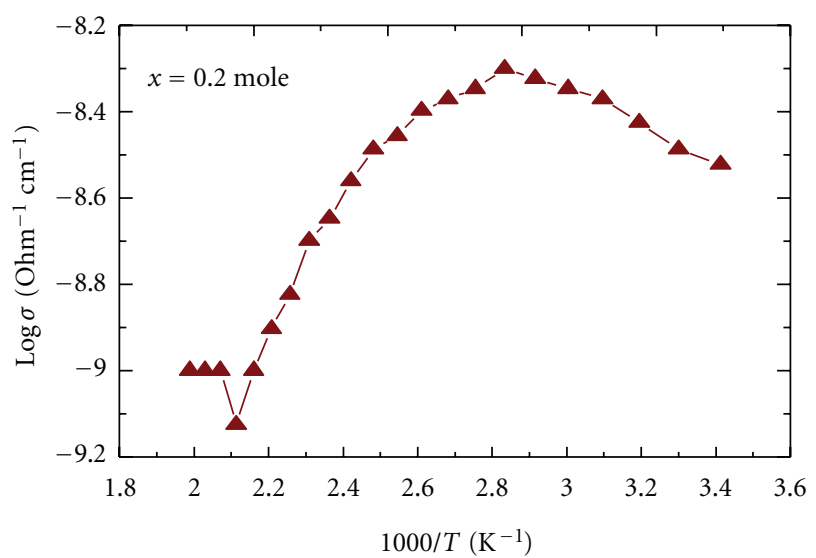

(d)

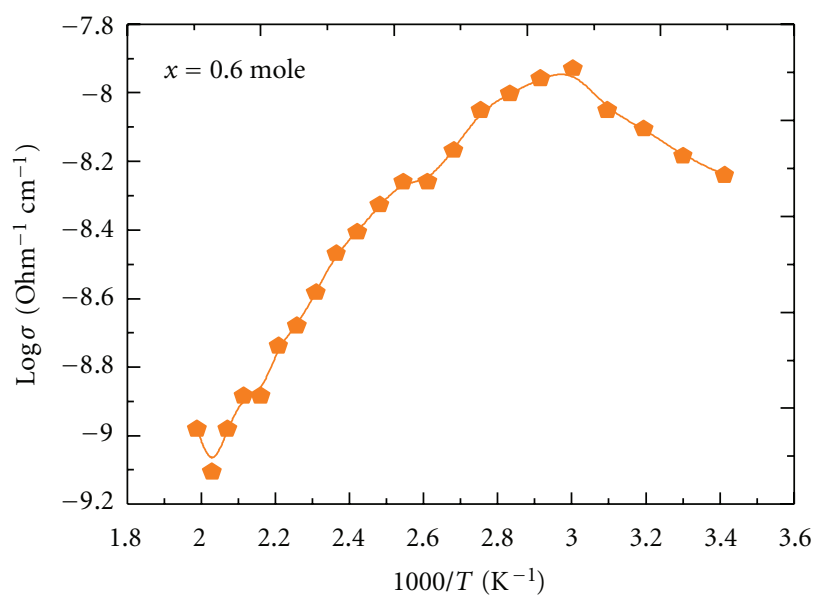

(f)

FIGURE 7: (a) The variation of DC-electrical conductivity as a function of temperature for pure 212-Bi-Sr-V-O system. (b) The variation of DC-electrical conductivity as a function of temperature for (b) $\mathrm{Bi}_{2} \mathrm{SrV}_{1.95} \mathrm{Mn}_{0.05} \mathrm{O}_{9}$. (c) The variation of DC-electrical conductivity as a function of temperature for (c) $\mathrm{Bi}_{2} \mathrm{SrV}_{1.9} \mathrm{Mn}_{0.1} \mathrm{O}_{9}$. (d) The variation of DC-electrical conductivity as a function of temperature for (d) $\mathrm{Bi}_{2} \mathrm{SrV}_{1.8} \mathrm{Mn}_{0.2} \mathrm{O}_{9}$. (e) The variation of DC-electrical conductivity as a function of temperature for (e) $\mathrm{Bi}_{2} \mathrm{SrV}_{1.7} \mathrm{Mn}_{0.3} \mathrm{O}_{9}$. (f) $\mathrm{Th}$ variation of DC-electrical conductivity as a function of temperature for (f) $\mathrm{Bi}_{2} \mathrm{SrV}_{1.6} \mathrm{Mn}_{0.4} \mathrm{O}_{9}$. 


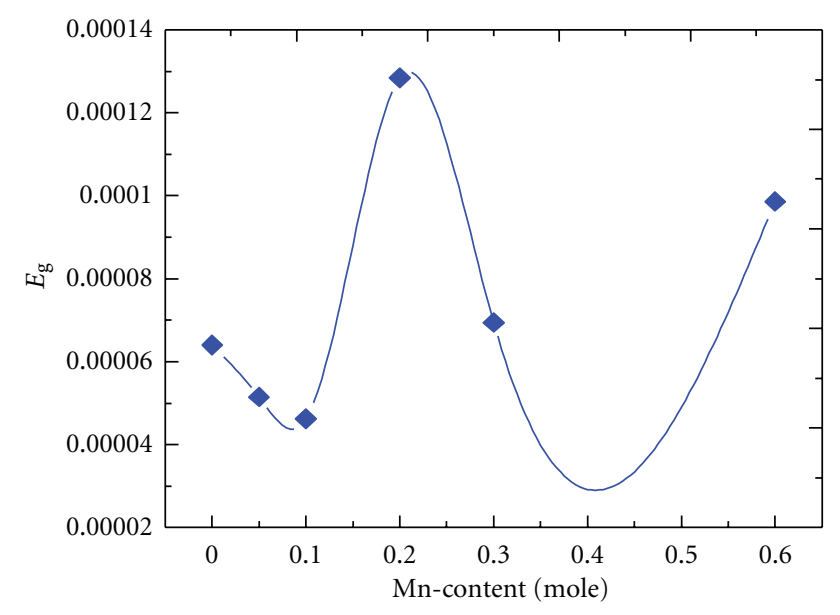

Figure 8: The variation of $E_{g}$ versus Mn-content ( $x$-values).

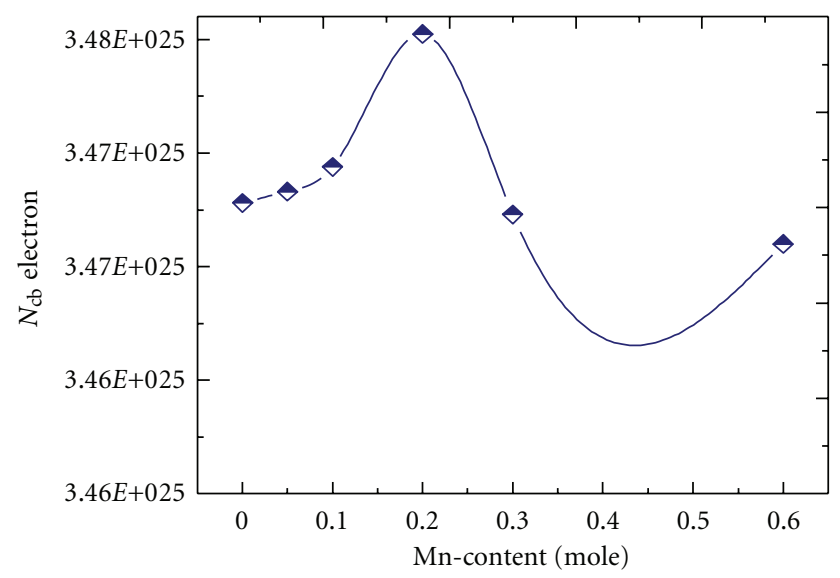

FIgUre 9: The variation of $N_{\mathrm{cb}}$ and Mn-content ( $x$-values).

so the values of $g \|$ and $g_{\perp}$ are many due to different oxidation state of $\mathrm{Mn}$ in the samples, and generally averaged $G_{\text {iso }}$ values are increased as Mn-dopant concentration increased from $x=0.05$ to $x=0.6$ mole.

3.3. DC-Electrical Conductivity Measurements. Figures 7(a)$7(\mathrm{f})$ shows the relation between DC-electrical conductivity $(\log \sigma)$ and reciprocal of absolute temperature $(1000 / T)$ $\mathrm{K}^{-1}$ as a function of $\mathrm{Mn}$ doping with the general formula $\mathrm{Bi}_{2} \mathrm{SrV}_{2-x} \mathrm{Mn}_{x} \mathrm{O}_{9}$, where $x=0.05,0.1,0.2,0.3,0.6$ mole.

Figure 7(a) displays two behaviors, the first is conducting (metallic behavior) since the conductivity decrease as the temperature rise and the second is semiconductor behavior in which the conductivity increases as the temperature rise. The samples with different $\mathrm{Mn}$ doping have the same behaviors as shown in Figures $7(\mathrm{~b})-7(\mathrm{f})$. Also we found that the energy gab $\left(E_{g}\right)$ and the number of $\left(\mathrm{e}^{-}\right)$in conduction band $N_{\mathrm{cb}}$ increases as the ratio of Mn doping increase from $x=0.05$ to $x=0.6$ mole (Figures 8and 9) [36], (See (1) and (2)).

In all cases Figures $7(\mathrm{a})-7(\mathrm{f})$ the results display semiconduction mechanism in the low temperature region and

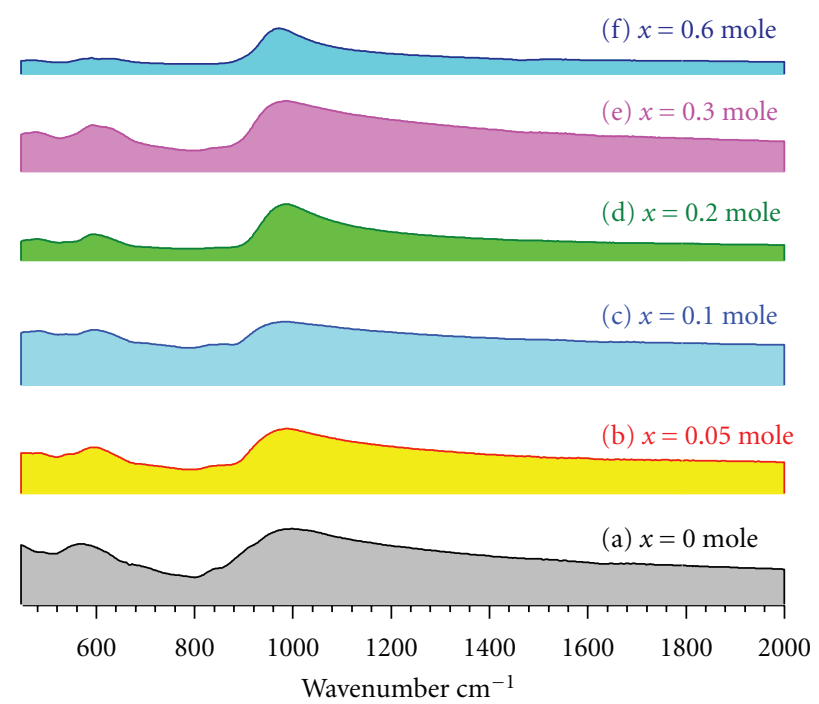

FIGURE 10: The room temperature solid infrared absorption spectra recorded for (a) pure $\mathrm{Bi}_{2} \mathrm{SrV}_{2} \mathrm{O}_{9}$, (b) $\mathrm{Bi}_{2} \mathrm{SrV}_{1.95} \mathrm{Mn}_{0.05} \mathrm{O}_{9}$, (c) $\mathrm{Bi}_{2} \mathrm{SrV}_{1.9} \mathrm{Mn}_{0.1} \mathrm{O}_{9}$, (d) $\mathrm{Bi}_{2} \mathrm{SrV}_{1.8} \mathrm{Mn}_{0.2} \mathrm{O}_{9}$, (e) $\mathrm{Bi}_{2} \mathrm{SrV}_{1.7} \mathrm{Mn}_{0.3} \mathrm{O}_{9}$, (f) $\mathrm{Bi}_{2} \mathrm{SrV}_{1.6} \mathrm{Mn}_{0.4} \mathrm{O}_{9}$.

metallic conduction mechanism in the high-temperature region.

Figure 8 displays the variation of energy gap $E_{g}$ as a function of Mn-dopant ratios. It is clear that the sample with $x=0.1$ mole is recording the minimum energy gap while the maximum energy gap was recorded for sample with $\mathrm{Mn}=x=0.2$ mole. These observations are enhanced by data recorded in Figure 9 as clear maximum number of electrons in the conduction band was for sample with $x=0.2$ mole.This means optimum ratio of Mn-dopings is equal to $x=0.2$ mole which is considered the boundary separates semiconduction and metallic behavior as shown in Figures $7(\mathrm{a})-7(\mathrm{f})$.

Sharma et al. [36] reported the synthesis of aurivilliustype phases incorporating magnetic $\mathrm{M}^{4+}$ cations $(\mathrm{M}=$ $\mathrm{Mn}, \mathrm{Ru}, \mathrm{Ir}$ ), based on the substitution of $\mathrm{M}^{4+}$ for $\mathrm{Ti}^{4+}$ in $\mathrm{Bi}_{2} \mathrm{Sr}_{2}(\mathrm{Nb}, \mathrm{Ta})_{2} \mathrm{TiO}_{12}$. They confirmed that the key to incorporating these magnetic transition metal cations appears to be the partial substitution of $\mathrm{Sr}^{2+}$ for $\mathrm{Bi}^{3+}$ in the $\alpha$-PbO-type layer of the aurivillius phase, leading to a concomitant decrease in the $\mathrm{M}^{4+}$ content; that is, the composition of the prepared compounds was $\mathrm{Bi}_{2-x} \mathrm{Sr}_{2+x}(\mathrm{Nb}, \mathrm{Ta})_{2+x} \mathrm{M}_{1-x} \mathrm{O}_{12}, x \approx 0.5$.

These compounds only exist over a narrow range of $x$, between an apparent minimum $(x \approx 0.4$ mole $) \mathrm{Sr}^{2+}$ content in the $\alpha$-PbO-type $\left[\mathrm{Bi}_{2} \mathrm{O}_{2}\right]$ layer required for aurivillius phase to form with magnetic $\mathrm{M}^{4+}$ cations and an apparent maximum $\left(x \approx 0.6\right.$ mole) $\mathrm{Sr}^{2+}$ substitution in this $\left[\mathrm{Bi}_{2} \mathrm{O}_{2}\right]$ layer.

Our results are partially consistent with Sharma et al. [36] such that the optimum Mn-ratio was for $x \sim 0.2$ mole in which maximum number of electrons was in conduction band.

3.4. Solid Infrared Absorption Spectral Measurements. The IR absorption spectra of pure 212BiSrV and Mn doped samples 
were carried out at room temperature in the IR range of $400-600 \mathrm{~cm}^{-1}$ as shown in Figure 10 (a)-(f). The system $2 \mathrm{2}^{2} \mathrm{BiSrVO}_{9} \pm \delta$ is mainly belongs to deficient perovskite structure and extra oxygen atom $\mathrm{O}_{9} \pm \delta$. Oxygen nine makes the structure to be distorted perovskite, so the vibrational modes of IR spectra of perovskite are closely appear.

In the system under investigation, the $\mathrm{V}$ site in the $\mathrm{ABO}_{3}$ crystal structure is being modified. Further, it is also well accepted that the displacement of $\mathrm{V}$ ions from its center caused ferroelectricity in these materials. Therefore an investigation of the infrared absorption is expected to reveal valuable information about the modification caused in the interatomic forces between $\mathrm{V}$ and $\mathrm{O}$ ions with the substitutions.

The IR absorption bands in the range of $400-600 \mathrm{~cm}^{-1}$ could be assigned to the stretching and bending modes of vibration of $\mathrm{Bi}-\mathrm{O}, \mathrm{Sr}-\mathrm{O}, \mathrm{V}-\mathrm{O} / \mathrm{Mn}-\mathrm{O}$ and $\mathrm{Bi}-\mathrm{O}-\mathrm{V}, \mathrm{Bi}-\mathrm{O}-\mathrm{Sr}$, respectively [37]. The band around $800 \mathrm{~cm}^{-1}$ is reported to be dominated by the motion of oxygen sub-lattice [38].

\section{Conclusions}

The conclusive remarks inside this paper can summarized in the following points:

(1) Mn substitutions succeeded on the $\mathrm{Bi}_{2} \mathrm{SrV}_{2-x} \mathrm{Mn}_{x} \mathrm{O}_{9}$ aurivillius structure;

(2) optimum concentration was found to be $x=0.2$ mole;

(3) Mn dopings interacted sharply with both of IR- and ESR-spectra;

(4) two kind of conduction mechanism were observed for Mn-aurivillus compounds;

(5) numbers of electrons evaluated $N_{\mathrm{cb}}$ at conduction band are enhanced by Mn dopings.

\section{References}

[1] J. F. Scott and C. A. Paz de Araujo, "Ferroelectric memories," Science, vol. 246, pp. 1400-1405, 1989.

[2] G. H. Haertling, "Ferroelectric thin films for electronic applications," Journal of Vacuum Science \& Technology A, vol. 9, no. 3, article 414, 7 pages, 1991.

[3] J. J. Lee, C. L. Thio, and S. B. Desu, "Electrode contacts on ferroelectric $\mathrm{Pb}\left(\mathrm{Zr}_{x} \mathrm{Ti}_{1-x}\right) \mathrm{O}_{3}$ and $\mathrm{SrBi}_{2} \mathrm{Ta}_{2} \mathrm{O}_{9}$ thin films and their influence on fatigue properties," Journal of Applied Physics, vol. 78, no. 8, article 5073, 6 pages, 1995.

[4] C. A. Pazde Araujo, J. D. Cuchlaro, L. D. McMillan, M. C. Scott, and J. F. Scott, "Fatigue-free ferroelectric capacitors with platinum electrodes," Nature, vol. 374, no. 6523, pp. 627-629, 1995.

[5] V. Volov, E. Vasco, P. Duran-Martin, and C. Zaldo, "Preferential orientation of modified $\mathrm{SrBi}_{2} \mathrm{Nb}_{2} \mathrm{O}_{9}$ ferroelectric thin films prepared by pulsed laser deposition," Applied Physics A, vol. 69, no. 7, pp. 833-836, 1999.

[6] J. R. Duclere, M. G. Viry, A. Pen-in et al., "Composition control of SBN thin films deposited by PLD on various substrates," International Journal of Inorganic Chemistry, vol. 3, no. 8, pp. 1133-1135, 2001.
[7] A. Boulle, C. Legrand, R. Guinebretiere, J. P. Mercurio, and A. Dauger, "X-Ray diffraction line broadening by stacking faults in $\mathrm{SrBi}_{2} \mathrm{Nb}_{2} \mathrm{O}_{9} / \mathrm{SrTiO}_{3}$ epitaxial thin films," Thin Solid Films, vol. 391, no. 1, pp. 42-46, 2001.

[8] X. Du and I. W. Chen, "Ferroelectric thin films of bismuthcontaining layered perovskites: part II, $\mathrm{PbBi}_{2} \mathrm{Nb}_{2} \mathrm{O}_{9}$," Journal of the American Ceramic Society, vol. 81, no. 12, pp. 3260-3264, 1998.

[9] X. H. Zhu, A. D. Li, D. Wu, T. Zhu, Z. G. Liu, and N. B. Ming, "High-resolution electron microscopy investigations on stacking faults in $\mathrm{SrBi}_{2} \mathrm{Ta}_{2} \mathrm{O}_{9}$ ferroelectric thin films," Applied Physics Letters, vol. 78, no. 7, pp. 973-976, 2001.

[10] P. Duran-martin, Substitutions effects on different sites of aurrivillius structure, Ph.D. thesis, University of Autonoma de Madrid, Madrid, Spain, 1997.

[11] P. Duran-Martin, A. Castro, P. Ramos, P. Millan, and B. Jimenez, "Ferroelectric anisotropy in layered compound type of Bi1.75Te0.25Sr0.75Na0.25Nb2O9," Boletines Sociedad de Cerámica y Vidrio, vol. 37, pp. 143-147, 1998.

[12] K. Watanabe, M. Tanaka, E. Sumitomo, K. Katori, H. Yagi, and J. F. Scott, "Spin-coated ferroelectric $\mathrm{SrBi}_{2} \mathrm{Nb}_{2} \mathrm{O}_{9}$ thin films," Applied Physics Letters, vol. 73, no. 1, pp. 126-129, 1998.

[13] J. H. Yi, P. Thomas, M. Manier, J. P. Mercurio, I. Jauberteau, and R. Guinebretiere, " $\mathrm{SrBi}_{2} \mathrm{Nb}_{2} \mathrm{O}_{9}$ ferroelectric powders and thin films prepared by Sol-Gel," Journal of Sol-Gel Science and Technology, vol. 13, no. 1-3, pp. 885-888, 1998.

[14] M. Mitsuya, K. Ishikawa, N. Nukaga, and H. Funakubo, "Preparation and characterization of $\mathrm{SrBi}_{2}\left(\mathrm{Ta}_{1-x} \mathrm{Nb}_{x}\right)_{2} \mathrm{O}_{9}$ thin films by metalorganic chemical vapor deposition from two organometallic source bottles," Japanese Journal of Applied Physics, vol. 39, pp. L620-L622, 2000.

[15] Y. Wu and G. Cao, "Ferroelectric and dielectric properties of strontium bismuth niobate vanadates," Journal of Materials Research, vol. 15, no. 7, pp. 1583-1590, 2000.

[16] Y. Wu and G. Z. Cao, "Enhanced ferroelectric properties and lowered processing temperatures of strontium bismuth niobates with vanadium doping," Applied Physics Letters, vol. 75 , no. 17, article 2650, 3 pages, 1999.

[17] H. Gu, J. M. Xue, and J. Wang, "Significant dielectric enhancement in $0.3 \mathrm{BiFeO}_{3}-0.7 \mathrm{SrBi}_{2} \mathrm{Nb}_{2} \mathrm{O}_{9}$," Applied Physics Letters, vol. 79, no. 13, article 2061, 3 pages, 2001.

[18] Y. Shimakawa, Y. Kubo, Y. Nakagawa, T. Kamiyama, H. Asano, and F. Izumi, "Crystal structures and ferroelectric properties of $\mathrm{SrBi}_{2} \mathrm{Ta}_{2} \mathrm{O}_{9}$ and $\mathrm{Sr}_{0.8} \mathrm{Bi}_{2.2} \mathrm{Ta}_{2} \mathrm{O}_{9}$," Applied Physics Letters, vol. 74, no. 13, article 1904, 3 pages, 1999.

[19] J. K. Lee, B. Park, K. S. Hong et al., "Effect of excess $\mathrm{Bi}_{2} \mathrm{O}_{3}$ on the ferroelectric properties of $\mathrm{SrBi}_{2} \mathrm{Ta}_{2} \mathrm{O}_{9}$ ceramics," Journal of Applied Physics, vol. 88, no. 5, article 2825, 5 pages, 2000.

[20] Y. Shimakawa, Y. Kubo, Y. Nakagawa, T. Kamiyama, H. Asano, and F. Izumi, "Crystal structure and ferroelectric properties of $\mathrm{ABi}_{2} \mathrm{Ta}_{2} \mathrm{O}_{9}(\mathrm{~A}=\mathrm{Ca}, \mathrm{Sr}$, and $\mathrm{Ba})$," Physical Review B, vol. 61, no. 10, pp. 6559-6564, 2000.

[21] I. Coondoo, A. K. Jha, and S. K. Agarwal, "Structural, dielectric and electrical studies in tungsten doped $\mathrm{SrBi}_{2} \mathrm{Ta}_{2} \mathrm{O}_{9}$ ferroelectric ceramics," Ceramics International, vol. 33, no. 1, pp. 41-47, 2007.

[22] R. D. Shannon and C. T. Prewitt, "Effective ionic radii in oxides and fluorides," Acta Crystallographica, vol. 25, pp. 925946, 1969.

[23] H. Taguchi, A. Shimizu, M. Nagao, and H. Kido, "Synthesis and characterization of four-layered hexagonal $\left(\mathrm{Sr}_{1-x} \mathrm{Ba}_{x}\right)$ 
$\mathrm{MnO}_{3}(0.0 \leq \mathrm{x} \leq 0.5)$," Journal of the Ceramic Society of Japan, vol. 115, pp. 77-80, 2007.

[24] T. Matsuoka, Y. Matsuo, H. Sasaki, and S. Hayagawa, "PTCR behavior of $\mathrm{BaTiO}_{3}$ with $\mathrm{Nb}_{2} \mathrm{O}_{5}$ and $\mathrm{MnO}_{2}$ Additives," Journal of the American Ceramic Society, vol. 55, no. 2, p. 108, 1972.

[25] H. Ueoka, "The doping effects of transition elements on the PTC anomaly of semiconductive ferroelectric ceramics," Ferroelectrics, vol. 7, no. 1, pp. 351-353, 1974.

[26] J. H. Choi, S. I. Lee, H. J. Sung, B.J. Park, and S. M. Jhon, "Comment on "preparation and electrorheological property of rare earth modified amorphous $\mathrm{Ba}_{x} \mathrm{Sr}_{1-x} \mathrm{TiO}_{3}$ gel electrorheological fluid"', Journal of Colloid and Interface Science, vol. 295, no. 1, pp. 291-293, 2006.

[27] S. J. Liu and N. G. Fan, "Thermal stability and influence of 3d-metals on aurrivilius phase," Chinese Journal of Chemical Physics, p. 367, 2006.

[28] E. Masiukaité, J. Banys, R. Sobiestianskas, T. Ramoska, V. A. Khomchenko, and D. A. Kiselev, "Conductivity investigations of Aurivillius-type $\mathrm{Bi}_{2.5} \mathrm{Gd}_{1.5} \mathrm{Ti}_{3} \mathrm{O}_{12}$ ceramics," Solid State Ionics, vol. 188, no. 1, pp. 50-52, 2011.

[29] B. Zulhadjri, B. Prijamboedi, A. A. Nugroho et al., "Aurivillius phases of $\mathrm{PbBi}_{4} \mathrm{Ti}_{4} \mathrm{O}_{15}$ doped with $\mathrm{Mn}^{3+}$ synthesized by molten salt technique: structure, dielectric, and magnetic properties," Journal of Solid State Chemistry, vol. 184, no. 5, pp. 1318-1323, 2011.

[30] A. Chakrabarti and J. Bera, "Structure and ferroelectric properties of $\mathrm{BaBi}_{3.8} \mathrm{M}_{0.2}\left(\mathrm{Ti}_{3.8} \mathrm{Nb}_{0.2}\right) \mathrm{O}_{15}(\mathrm{M}=\mathrm{Mg}, \mathrm{Ca}, \mathrm{Sr}$ and $\mathrm{Ba})$ ceramics," Physica B, vol. 406, no. 14, pp. 2891-2897, 2011.

[31] M. Mazurek, E. Jartych, A. Lisińska-Czekaj, D. Czekaj, and D. Oleszak, "Structure and hyperfine interactions of $\mathrm{Bi}_{9} \mathrm{Ti}_{3} \mathrm{Fe}_{5} \mathrm{O}_{27}$ multiferroic ceramic prepared by sintering and mechanical alloying methods," Journal of Non-Crystalline Solids, vol. 356, no. 37-40, pp. 1994-1997, 2010.

[32] N. L. Amsei, A. Z. Simoes, A. A. Cavalheiro, S. M. Zanetti, E. Longo, and J. A. Varela, "Structural and microstructural characterization of $\mathrm{SrBi}_{2}\left(\mathrm{Ta}_{0.5} \mathrm{Nb}_{0.48} \mathrm{~W}_{0.02}\right)_{2} \mathrm{O}_{9}$ powders," Journal of Alloys and Compounds, vol. 454, no. 1-2, pp. 61-65, 2008.

[33] I. Onyszkieuicz, P. Czarnecki, R. Mienas, and S. Robaszkiew1ez, "Spectroscopic studies of the high- $\mathrm{T}_{c}$ superconducting cuprate perovskites," Physica, vol. 147, no. 2-3, pp. 166-174, 1988.

[34] T. Hidaka, "Electronic instability of the $\Gamma_{15}$ phonon in $\mathrm{BaTiO}_{3}$," Physical Review B, vol. 20, pp. 2769-2773, 1979.

[35] A. Simpson and E. Robert, Introductory Electronics for Scientists \& Engineers, Allyn and Bacon, 2nd edition, 1987.

[36] N. Sharma, C. D. Ling, G. E. Wrighter, P. Y. Chen, B. J. Kennedy, and P. L. Lee, "Three-layer Aurivillius phases containing magnetic transition metal cations: $\mathrm{Bi}_{2-x} \mathrm{Sr}_{2+x}$ $(\mathrm{Nb}, \mathrm{Ta})_{2+x} \mathrm{M}_{1-x} \mathrm{O}_{12}, \mathrm{M}=\mathrm{Ru}^{4+}, \mathrm{Ir}_{4+}, \mathrm{Mn}_{4+}, x \approx 0.5$, , Journal of Solid State Chemistry, vol. 180, no. 1, pp. 370-376, 2007.

[37] S. R. Kokare, S. A. Pawar, N. T. Padal, and P.B. Joshi, "Studies on compensating valency substituted $\mathrm{BaTi}_{(1-x)} \mathrm{Mn}_{x / 2} \mathrm{Nb}_{x / 2} \mathrm{O}_{3}$ ceramics," Bulletin of Material Science, vol. 42, no. 2, pp. 243 $248,2001$.

[38] N. Syam and K. B. Varma, "Nanocrystallization of $\mathrm{SrBi}_{2} \mathrm{Nb}_{2} \mathrm{O}_{9}$ from glasses in the system $\mathrm{Li}_{2} \mathrm{~B}_{4} \mathrm{O}_{7} \mathrm{SrOBi}_{2} \mathrm{O}_{3} \mathrm{Nb}_{2} \mathrm{O}_{5}$," Materials Science and Engineering B, vol. 90, no. 3, pp. 246-253, 2002. 


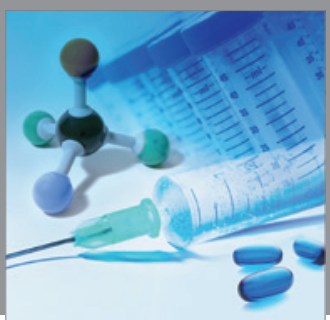

International Journal of

Medicinal Chemistry

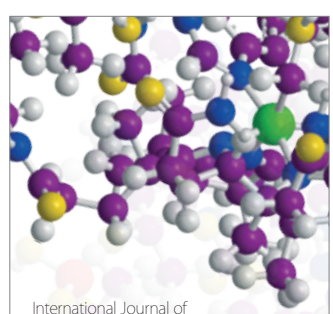

Carbohydrate Chemistry

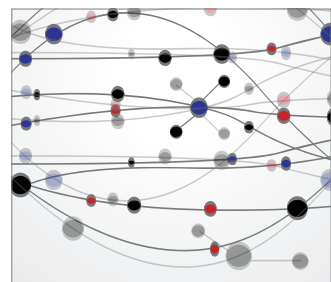

The Scientific World Journal
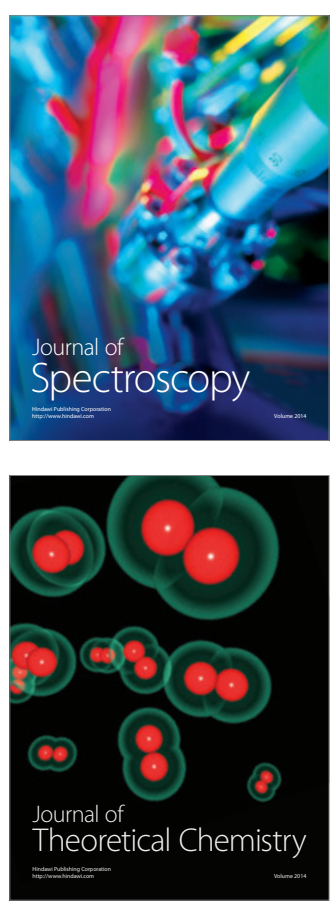
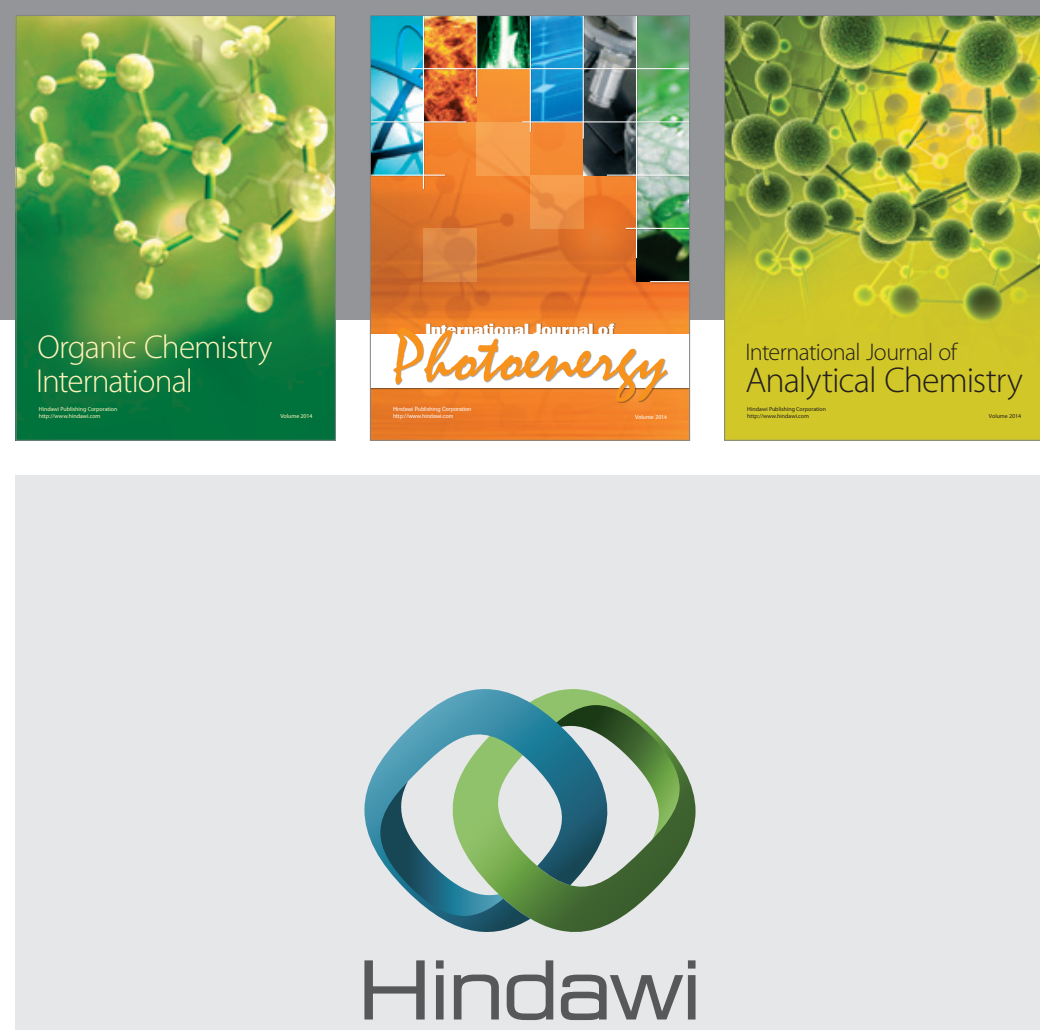

Submit your manuscripts at

http://www.hindawi.com
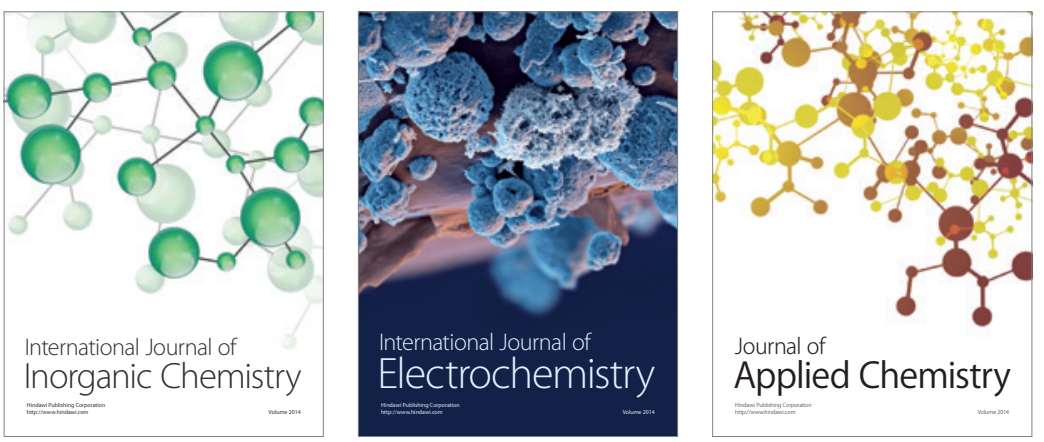

Journal of

Applied Chemistry
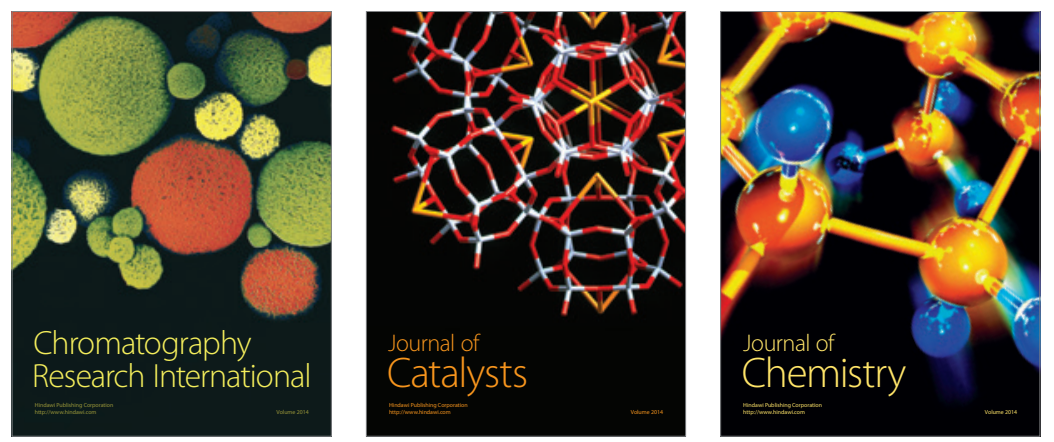
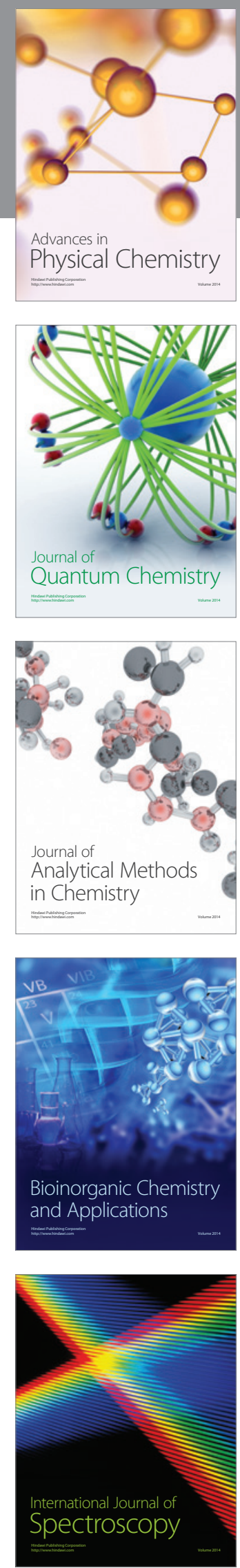